\title{
ОБНОВЛЕНИЕ ЕВРОПЕЙСКИХ ВЛАСТНЫХ СТРУКТУР: ПОИСК ИДЕНТИЧНОСТИ
}

\begin{abstract}
Аннотация. В последние годы происходит прочесс обновления политических элит. Ослабевают позищии консерваторов, сочиал-демократов, либералов. Им на смену постепенно приходят партии «политической альтернативы» - прежде всего, начионалисты и сочиалпопулисты. Первые уже вошли в правительства ряда стран Северной и Центральной Евроnы. Популисты находятся у власти в странах Средиземноморья. В ряде других государств они стали частью внепарламентской оппозиции.
\end{abstract}

Ключевые слова: партии, националисты, популистьл, власть, Евросоюз.

Смена элит на политическом олимпе - процесс вполне закономерный и, как правило, связанный с возрастными обстоятельствами. Долголетие в политике имеет, однако, не только чисто биологические параметры, определяющие возможность соответствующих деятелей выполнять возложенные на них функции. Необходимость покинуть арену высокой политики возникает тогда, когда исчерпывается потенциал влияния на процессы, происходящие как в отдельной стране, так и за её пределами. Причём соответствующие лимиты касаются как лидеров тех или иных партий, так и самих субъектов политики.

Подтверждением этой истины стало развитие Евросоюза в первые почти два десятилетия XXI в. От эйфории якобы почти очевидных успехов в сфере экономики наступило отрезвление в условиях разнообразных кризисов финансово-хозяйственной сферы. От энтузиазма, связанного с ожидавшимся притоком необходимой для ЕС рабочей силы, к тревоге от её слабо контролируемого потока в середине второго десятилетия. От теоретически обоснованных надежд, связанных с пополнением рядов сообщества, к констатации проблем, вытекавших из разнородности новичков - участников ЕС. От веры в нерушимость основного ядра Союза, сформировавшегося ещё в последнее десятилетие века минувшего, к брекзиту и реальной возможности умножения таких «экзитов» за счёт стран, неуютно чувствующих себя в новом, практически необжитом доме. От обоснованной вначале надежды на взаимовыгодное партнёрство с США, Китаем, Россией, другими ключевыми игроками на мировой арене к острому кризису взаимоотношений. И не только из-за смены лидеров в упомянутых государствах, но и вследствие изменившихся объективных обстоятельств современного мира.

В этих условиях традиционные европейские политические элиты должны были либо найти в ограниченный временной промежуток новые нестандартные решения обрушившихся на них проблем, либо уступить место тем, кто готов был хотя бы декларативно возглавить поиск новых путей продвижения к цели - всесторонне гармоничной Европе. Однако неизбежная в кризисных обстоятельствах смена элит протекала без какой-либо внутренней гармонии, скорее импульсивно, чем планомерно. Всё вышесказанное относится к странам, вступившим в Евросоюз до его расширения в начале нынешнего тысячелетия. Что касается стран, вступив-

(C) Швейцер Владимир Яковлевич - доктор исторических наук, главный научный сотрудник, руководитель Отдела социальных и политических исследований ИЕ РАН. Адрес: 125009, Россия, Москва, ул. Моховая, д. 11, стр. 3. E-mail: partsist@ list.ru.

DOI: http://dx.doi.org/10.15211/vestnikieran120194347 
ших в EC в начале XXI в., то у них можно узреть тенденцию перехода власти от либеральноконсервативного к националистическому классу политиков.

Европейский избиратель, участвуя в последние годы в выборах различного уровня (президентских, парламентских, местных), в референдумах любого масштаба учитывает при принятии решений весь комплекс сопутствующих этим мероприятиям обстоятельств. Здесь и итоги правления тех, кто уже находится у власти, и убедительность контраргументов оппозиции, и фактор скандальных разоблачений (подтверждённых документально либо достаточно сомнительных), касающихся главных действующих лиц политического процесса. Результаты выборов отражают двухмерность основной традиционной логики избирателей: опасения возможного ухудшения своего, прежде всего, социально-экономического положения либо слабую надежду на какие-либо перемены позитивного свойства.

Электоральные итоги политической борьбы являются в конечном счёте основным фактором, способствующим обновлению властных структур. При этом избиратель, в зависимости от национально-психологических особенностей и политических традиций той или иной страны либо группы стран, склонен или передоверить власть новым людям из числа традиционных субъектов политики, или же передать её новым политическим силами и их элите. Однако в странах Западной Европы второй половины нынешнего десятилетия проявился и неожиданный внешний фактор - нетипичная смена власти в США. На её вершине оказался человек, по существу не связанный с выдвинувшей его на высокий пост политической партией. Эта нетипичная подвижка оказала своё воздействие и на переформатирование верхнего этажа европейского партийного ареопага. В двух ведущих странах Старого Света - Франции и Италии у штурвала государства оказались новички политических баталий, поддержанные созданными по нетрадиционным политическим лекалам движениями особого свойства.

Перемены текущего десятилетия на партийном олимпе Европы открыли нам многообразие вариантов обновления властных структур. Общим же для различных политических комбинаций стало то, что традиционный истеблишмент был серьёзно потеснён партиями и движениями политической альтернативы. Их альтернативность в разных странах выглядит поразному, однако в целом обозначились три основных отряда обновляемого партийного ландшафта Европы.

Наиболее сильными и влиятельными в электоральном отношении являются националисты. Политический курс партий этого спектра европейской партийной системы можно, в первом приближении, обозначить как национал-эгоизм. В сфере внешней политики и международных отношений эти партии отстаивают сугубо национальные интересы, отодвигая на второй план уже сложившуюся систему глобальных и интеграционных связей, пренебрегая реальным местом своих стран в системе мировой экономики и политики. Во внутренней политике национал-эгоизм проявляется в защите интересов исключительно коренных жителей своей страны, в негативном отношении к согражданам иной расы и вероисповеданий. Их альтернативность, прежде всего, касается нечёткой, не просчитанной в деталях иммиграционной политики власть предержащих. Они пропагандистски обыгрывали неготовность европейского социального государства «переварить» большое количество «новых европейцев», которым предоставлено убежище. Националисты набрали очки и на правовом поле, обратив внимание на очевидные просчёты властей в деле защиты своих граждан от криминально-террористической угрозы, во многом порождённой недостаточно контролируемым наплывом беженцев и иммигрантов.

Свою альтернативу очевидным пробелам в сфере региональных, а в отдельных случаях и межгосударственных проблем выдвигают регионал-сепаратисты. Диапазон их претензий 
достаточно широк: от повышения статуса соответствующих регионов до требования образовать новые независимые государства. Кое-где ставится вопрос и об изменении государственных границ, не устраивающих часть населения, тяготеющую к исторической родине. В своих требованиях сепаратисты делают акцент на несправедливом распределении экономических благ в традиционных многоэтничных государствах, а также на неудовлетворительное финансирование из центра. Недовольны сепаратисты и явно недостаточными, с их точки зрения, представительскими функциями регионов в различных структурах Евросоюза.

Современные социал-популисты политически эксплуатируют как уже упомянутые реперные точки европейской политики, так и другие темы, не оценённые должным образом в практике правящих партий истеблишмента. Они подменяют детальный анализ современной ситуации в Европе изощрённой политической демагогией. Это темы борьбы с бюрократизмом и коррупцией, несправедливого распределения национального дохода, роли и места своего государства в интегрируемой Европе. Они предлагают паллиативные, практически нереализуемые решения, адресат которых - политически разномастные слои населения. Особенность современного популизма заключается в его способности интегрировать в свои ряды сторонников радикальных взглядов, как правого, так и левого толка.

К партиям политической альтернативы можно с некоторыми оговорками причислить и экологистов. Правда, в их рядах наметилась определённая дифференциация тех, кто готов искать компромисс между экономическими доминантами и экологическими ценностями, и тех, кто считает последние альфой и омегой своего политического курса.

Географически весь обновляемый партийный ландшафт Европы может быть условно поделён на две основные части. В южноевропейском регионе лишились прежних властных полномочий консерваторы Греции, Италии, Испании и Португалии. Им на смену пришли ещё совсем недавно малозаметные игроки политического поля - СИРИЗА в Греции и «Движение пяти звёзд» в Италии. На Пиренеях ранее уже наработавшие политический капитал испанские и португальские социалисты существенно обновились и программно и персонально, что позволило новым лидерам стать первыми фигурами на политической шахматной доске. Южноевропейский вариант смены власти характерен тем, что новички из партий и движений политической альтернативы не решились в одиночку осваивать малопредсказуемое политическое пространство. Отсюда и длившаяся несколько лет коалиция с правыми националистами в Греции. В Италии в роли партнёра выступают национал-сепаратисты, где партия «Лига Севера» из тактических соображений сняла из названия свою региональную ориентацию, став просто «Лигой». На Пиренеях местные социалисты подстраховались слева, причём в португальском варианте в союзники были приглашены бывшие коммунисты, левые социалисты и экологисты, а в Испании неустойчивые политические позиции ИСРП страховали до последнего времени леворадикалы из «Подемос» и умеренные сепаратисты ряда национальных автономий.

Иная ситуация в противоположной части Европы - в Скандинавии. В Дании партия либералов - фавориты местного политического истеблишмента - не без оснований рассчитывает в парламенте на голоса националистов из Датской народной партии. Аналогичная ситуация в соседней Норвегии, где антииммигрантская Партия прогресса уже прочно освоила места в коалиционном кабинете вместе с правыми либералами и демохристианами. Поначалу складывалось межпартийное сотрудничество таких же политических сил в Финляндии. Однако местные националисты из «Истинных финнов» разошлись между собой во мнениях по иммигрантской тематике. В результате одна часть осталась в коалиции с либералами и консерваторами, а другая стала оппозиционной. В соседней Швеции националисты из «Шведских демократов постоянно наращивают свой электоральный багаж. Косвенно влияют на формирова-

Научно-аналитический вестник ИЕ РАН, 2019, №1 
ние правительства под угрозой создания коалиции буржуазных партий с националистами бесспорные лидеры шведской политики - социал-демократы, вынужденные отказаться от своих традиционных социальных программ ради сохранения политического нейтралитета с частью либералов и демохристианами.

В таких небольших странах Европы, как Австрия, Нидерланды, Бельгия, Швейцария националистический тренд также способствовал укреплению партий политической альтернативы правого толка. В Австрии Партия Свободы вошла в правительство, возглавляемое консервативной Народной партией, которая по теме иммиграции явно сблизилась с АПС. В Нидерландах также наблюдается процесс усиления влияния националистов одноимённой Партии Свободы, постоянно укрепляющей свои позиции в местных органах власти, потенциально готовых вступить в коалицию с правыми партиями. В Бельгии очевидно усиление позиции Нового фламандского альянса, который совмещает в своей идеологии и политике сепаратистские и националистические воззрения. В Швейцарии национал-изоляционисты из Народной партии прочно занимают лидирующие позиции в центральных органах власти.

Процесс обновления властных структур не миновал Германию и Великобританию, наиболее стабильные в экономическом и политическом отношении европейские державы. Тема брекзита для Великобритании и иммиграционный вопрос для Германии стали катализаторами глубинных перемен в элитарных структурах местного истеблишмента. На туманном Альбионе суровые ветры брекзита не только способствовали реальному расколу в стане консерваторов, но и сделали достаточно неопределённой судьбу самой консервативной партии. Сегодня Т. Мэй не является её бесспорным лидером и вынуждена признать возможность своего скорого ухода с Даунинг-стрит. Самой партии консерваторов предстоит нелёгкий выбор между окончательным сползанием к национал-изоляционизму и поиском новых форм сотрудничества со своими прежними единомышленниками в континентальной Европе. В Германии, ещё не оправившейся от незапланированного наплыва иммигрантов в середине нынешнего десятилетия, лидер ХДС А. Меркель стремится обеспечить партии плавный переход власти к группе новых лидеров. Сроки ухода «Канцлерин» в отставку с высшего государственного поста уже определены, а партийный пост номер один заблаговременно передан А. Крампф-Карренбаэур. Однако под большим сомнением лояльность партнёра - Христианско-социального союза, где сменились местные баварские лидеры.

На фоне персональных перемен в элите европейского истеблишмента достаточно нетипично выглядит то, что произошло в последние годы во Франции. Выборы 2017 г. показали, что в проигрыше оказались оба политических тяжеловеса - и неоголлисты (республиканцы) и социалисты. Укрепили свои электоральные позиции, однако не приблизились к рычагам исполнительной власти их главные оппоненты - националисты (М. Ле Пен) и социал-популисты (Ж.-Л. Меланшон). В этой ситуации появление Э. Макрона и наспех собранного им движения - Партии «Вперёд, Франция» - выглядело вполне закономерно, ибо в политике никогда не бывает вакуума. Последующие события подтверждают банальную истину: случайное стечение обстоятельств, без заранее апробированных, хотя бы декларативно, альтернатив, не сулит новым элитам спокойной жизни. Ведь сам нынешний президент Франции, в отличие от своих предшественников - лидеров Пятой республики - пришёл к власти, не имея ни солидного политического бэкграунда, ни сплочённой команды единомышленников, ни широкой массовой поддержки.

Появление «жёлтых жилетов» в качестве общественно-политической альтернативы нельзя не связать с отсутствием сложившейся оппозиции, как справа, так и слева. Процесс формирования таковой ещё продолжается, сопровождаясь чередой внутренних расколов и размеже- 
ваний бывших соратников - М. Ле Пен и Ж.-Л. Меланшона. С другой стороны, к крайне правым и крайне левым начинают постепенно подтягиваться некоторые знаковые фигуры из стана неоголлистов и социалистов. Не исключено, что движение «жёлтых жилетов» может обрести вполне реальные партийно-политические формы. Как, кстати говоря, получилось в Италии, где «Движение пяти звезд» стало не комическим, как казалось вначале, а вполне политическим оппонентом партийного пространства на Апеннинах. Опять-таки, этому способствовал разброд в прежних элитах, где до сих пор бушуют страсти в лагерях консерваторов-берлускониевцев и неосоциал-демократов.

Определённую ясность в общеевропейский расклад партийных сил могут внести выборы в Европейский парламент, которые состоятся в мае этого года. Однако переоценивать их итоги всё же не стоит, учитывая тот традиционно незначительный, по сравнению с национальными выборами, интерес к ним европейского электората. Тем не менее, предстоящее общеконтинентальное голосование в целом обозначит отношение европейцев к смене элит, к поиску последними новой политической идентичности.

\section{Renovation of the European Power Structures: in the Search of Identity}

Author. Vladimir Schweitzer, Doctor of Sciences (History), Head of Department for Social and Political Research, Institute of Europe, Russian Academy of Sciences. Address: 11-3 Mokhovaya str.t, Moscow, Russia, 125009. E-mail: partsist@ list.ru.

Abstract. In recent years, there has been a process of renewal of political elites. The positions of conservatives, social democrats and liberals are weakening. They are gradually replaced by parties of «political alternative» - in the first place, by nationalists and social populists. The first are already included in the governments of a number of countries in Northern and Central Europe. Populists are in power in the Mediterranean. In a number of other States, they have become part of the extra-parliamentary opposition.

Key words. Nationalists, populists, power, European Union.

DOI: http://dx.doi.org/10.15211/vestnikieran120194347 